\title{
EFFECTS OF AFFILIATION WITH THE FINANCIAL CONGLOMERATE ON BANK LIQUIDITY AND SOLVENCY IN THE VISEGRAD COUNTRIES
}

\author{
[Vliv př́slušnosti k finanční skupině na likviditu a solventnost bank ve \\ Visegrádských zemích]
}

\author{
Pavla Klepková Vodová ${ }^{1}$ \\ ${ }^{1}$ Silesian University, School of Business Administration, Univerzitní nám. 1934/3, 73340 Karviná \\ Email:klepkova@opf.slu.cz
}

\begin{abstract}
The aim of this paper is to evaluate the liquidity and solvency of commercial banks in the Visegrad countries during the 2000-2016 period and to determine whether banks that belong to a financial conglomerate are more or less liquid and solvent than other banks in the sector. We used four liquidity ratios and one solvency ratio and compared the value of these ratios of banks with the median values in each banking sector. We will focus on banks from five financial conglomerates: Erste Group, KBC Group, Raiffeisen Bank International AG, Société Générale Group and UniCredit Group. All banks that belong to a financial conglomerate in Hungary are more solvent and mostly more liquid than other banks in the Hungarian banking sector. Banks from all analyzed groups held a higher buffer of liquid assets and mostly focus less on providing loans to non-bank customers. As the other results are mixed (for individual financial groups, individual countries, individual financial ratios), we cannot confirm that banks in a financial conglomerate are more or less liquid and solvent than other banks in the banking sector.
\end{abstract}

Keywords: banking sector, financial conglomerate, financial ratio, liquidity, solvency, Visegrad countries.

JEL classification: G21, G32

Doručeno redakci: 30.12.2017; Recenzováno: 15.1.2018; 18.1.2018; Schváleno k publikování: 13.6.2018

\section{Introduction}

The emergence of financial conglomerates is one of the major trends in the financial sector in recent years. Financial conglomerates are often linked with higher risks arising from the possibility of regulatory arbitrage, risk of contagion within the group, moral hazard (first, there is a risk of the non-regulated entity in the group; second, the conglomerate may become so large that it is perceived as "too big to fail" by market participants), lack of transparency for market participants and supervisors, conflict of interest in different roles in customerdealing, and the possibility of abuse of economic power (Dierick 2004). As financial conglomerates are often systematically important financial institutions in many countries, it is evident that their financial stability is crucial for the financial stability of whole banking sectors. Among other relevant aspects of the banking business, liquidity and solvency are important.

The aim of this paper is, therefore, to evaluate the liquidity and solvency of commercial banks in the Visegrad countries during the 2000-2016 period and to determine whether banks that belong to a financial conglomerate are more or less liquid and solvent than other banks in the sector. The group of Visegrad countries (V4) consists from Czech Republic, Hungaria, Poland, and Slovakia. Although all Visegrad countries are characterized by a universal banking model, activities of banks in the financial markets significantly differ. 
The structure of the paper is as follows. The next section provides a theoretical background on bank liquidity and solvency. Then, we focus on the methodology, data and results of the analysis. The final section offers concluding remarks.

\section{Bank Liquidity and Solvency}

Each bank has to be liquid, i.e. must be able to fund increases in assets and meet obligations as they come due, without incurring unacceptable losses (BIS 2008). Liquidity is somehow interpreted as the capability of a bank to raise funds in the wholesale financial markets, mainly in the unsecured interbank market, by increasing its liabilities. Liquidity can, therefore, be considered as the aptitude of a bank to acquire funds when these funds are needed (Vento and La Ganga 2009). The risk that the bank will not have enough liquidity arises from the stochastic nature of the bank liquidity: although the bank can be liquid at any given time, there may be quite unpredictable situations such as unexpected utilization of credit lines, unforeseen deposit withdrawals, untimely loan redemption, a liquidity need resulting from asset price developments or failed or delayed payments by sellers of credit risk protection which can threaten bank liquidity (ECB 2002). To ensure that the bank will be liquid at any time, adequate liquidity risk management is essential. The aims of liquidity risk management are: (i) to ensure that all times an adequate corresponding balance between cash inflows and cash outflows, thus guaranteeing the solvency of the bank, (ii) to coordinate the issuing by the bank of short, medium and long term financing instruments, (iii) to optimize the costs of refinancing, striking a trade-off balance between liquidity and profitability, (iv) and to optimize, for banks structured as banking groups, the intra-group management of cash flows, with the aim of reducing dependence on external financial requirements, by means of cash pooling techniques or other optimization instruments (Ruozi and Ferrari 2013).

Solvency (i.e. the ability to meet its long-term financial obligations) is a necessary condition of the business of financial conglomerates, too. Bank capital plays a key role in bank solvency: the more capital banks have, the more robust their buffers are with which to absorb unexpected losses (Bikker and Metzemakers 2007). Solvency in the banking sector is required also by regulators from the end of the nineties.

Liquidity and solvency are connected: a solvent institution should not have problems to obtain liquid funds. Once the capital adequacy worsens, the need to ensure sufficient liquidity is becoming more important. The illiquid institution can rapidly become insolvent and vice versa. Experience from financial and banking crises in several countries during the last decades have made both regulatory and supervisory authorities and the financial institutions themselves more aware of the importance of a sufficient level of liquidity and solvency.

Two different theories explain the link between capital adequacy and bank liquidity (Berger and Bouwman 2009). The financial fragility-crowding-out hypothesis suggests that bank capital may impede liquidity creation by making the bank's capital structure less fragile. A fragile capital structure encourages the bank to commit to monitoring its borrowers, and, hence, allows it to extend loans. Additional equity capital makes it more difficult for less fragile banks to commit to monitoring, which in turn hampers the bank's ability to create liquidity. Capital may also reduce liquidity creation because it crowds out deposits. This negative relationship between bank liquidity and capital adequacy has been reported by Berger and Bouwman (2009), Diamond and Rajan (2001), Dinger (2009), Distinguin et al. (2013), Gorton and Winton (2000), Lei and Song (2013), Munteanu (2012), and Vodová (2013a and 2015). An alternative view - the risk absorption hypothesis - is related to banks' role as risk transformers and emphasizes that higher capital improves banks' ability to absorb 
risk and hence their ability to create liquidity. This theory has been confirmed by Berger and Bouwman (2009), Berrospide (2013), and Vodová (2013a and 2015).

In spite of an increasing number of financial conglomerates and of the higher attention of regulators and supervision bodies to financial conglomerates, their liquidity, and solvency, an important gap still exists in the empirical literature. Papers dealing with financial conglomerates are mostly only theoretical, focusing on various aspects of risk management and capital adequacy of the conglomerate. Empirical studies deal mainly with diversification benefits and conglomerate discounts. We can find studies that examined the efficiency of European banks, such as Vander Venet (2002) or Palečková (2017). Vander Vennet (2002) found that conglomerates were more revenue efficient than their specialized competitors. On the contrary, Palečková (2017) did not confirm that banks from a financial conglomerate are more or less efficient than other banks in the banking sector in the Visegrad countries. However, we cannot find studies focusing on the link between liquidity and solvency and the affiliation of the bank with a financial conglomerate. This paper, therefore, tries to fill this gap in current empirical research.

\section{Methodology and Data}

First, we will evaluate the level of bank liquidity for each bank in the sample using the following commonly employed liquidity ratios: the liquid asset ratio, the loan-to-asset ratio, the loan-to-deposit ratio and the net interbank position (Vodová 2013b). The liquid asset ratio (LITA) is the share of liquid assets in total assets. This ratio should give us information on a bank's capacity to absorb a general liquidity shock. As a general rule, the higher the ratio, the higher the capacity to absorb liquidity shock is, provided that market liquidity is the same for all banks in the sample. We use the Orbis Bank Focus measure of liquid assets which includes cash, government bonds, short-term claims on other banks (including certificates of deposit), and where appropriate the trading portfolio.

The loan-to-asset ratio (LOTA) is the share of loans in total assets. Therefore, it indicates what percentage of the assets of the bank is tied up in illiquid loans. The higher the value of this ratio, the less liquid the bank is. However, the too low value of this ratio may indicate that the bank does not provide loans sufficiently. This could lower bank profitability.

The loan-to-deposit ratio (LODE) relates illiquid assets to liquid liabilities. The share of loans in deposits may be interpreted as follows: the higher this ratio the less liquid the bank is. This loan to the deposit ratio also provides information which part of loans provided to non-bank clients is financed from deposits of non-bank customers. Values lower than $100 \%$ mean that loans are fully financed from clients' deposits. Values higher than $100 \%$ signal that the bank needs also another source of funding such as interbank loans or funds from debt securities issuance. Although large proportions of clients' deposits are in the form of demand deposits, they are generally a stable source of funding. In terms of liquidity risk, banks should prefer a lower value of this ratio. A high value of the LODE ratio indicates that the bank is more vulnerable, especially in case of market turbulence.

The net interbank position (NIP) captures the activity of banks on the interbank market. To be able to compare different-sized banks, this ratio measures the share of a net interbank position (i.e. the difference between dues from banks and dues to banks) in the total assets of the bank. The value of this ratio is positive for net lenders and negative for net borrowers. Comparing with clients' deposits, raising funds in the interbank market is significantly more flexible. However, due to the low stability of this source of funding (a bank is constantly under the 
control of its counterparties which in case of doubts about the financial situation of the bank may not roll over loans), it is riskier. Banks who are net borrowers are thus much more vulnerable.

To assess the solvency of each bank in the sample is much more difficult. Due to the lack of consistent date, it was possible to use neither total capital ratio nor Tier 1 ratio. The only capital adequacy indicator which we could use is only the share of equity in total assets (CAP). It is a very simplified way how to measure bank capital adequacy (solvency). The higher the equity-to-asset ratio, the lower risk of bank insolvency. However, this ratio does not reflect the different quality of bank capital (tier 1, tier 2) or different riskiness of bank activities.

Next, we will examine whether the banks that belong to a financial conglomerate are more liquid and solvent than other banks. We will compare the value of the above mentioned financial ratios of banks with the median values of these ratios in each banking sector. We will focus on banks from five financial conglomerates: Erste Group, KBC Group, Raiffeisen Bank International AG, Société Générale Group and UniCredit Group.

The dataset used in this paper was obtained from the Orbis Bank Focus database and the annual reports of commercial banks during the 2000-2016 period. All the data are reported on an unconsolidated basis. Due to the homogeneity of the data set, we include only data from commercial banks that are operating as independent legal entities. We exclude branches of foreign banks, mortgage banks, building societies and state banks with special purposes (such as Českomoravská záruční a rozvojová banka, Slovenská záručná a rozvojová banka, Česká exportní banka, Exim banka, Magyar Fejlesztési Bank or Bank Gospodarstwa Krajowego). The national panels are unbalanced because some banks do not report or exist over the full period of analysis. The sum of total assets of selected commercial banks covered more than $70 \%$ of total assets of the banking sector.

\section{Results and Discussions}

The first part of this section presents the median values of liquidity and solvency ratios for banking sectors in the Visegrad countries. The second part of this section focuses on banks belonging to five selected financial conglomerates.

Bank liquidity is strongly influenced by the lending policy of the bank. Banks that focus more on lending to non-bank customers usually hold a lower level of liquid assets. On the contrary, banks that prefer operations on the interbank market may have higher claims on banks which result in a higher buffer of liquid assets. Table 1 presents the median values of the liquid asset ratio (LITA), Table 2 focuses on the share of loans in total assets (LOTA) in Visegrad countries' banking sectors within the 2000-2016 period.

Table 1: Median values of the LITA ratio

\begin{tabular}{|l|c|c|c|c|c|c|c|c|c|c|c|c|c|c|c|c|c|}
\hline & 00 & 01 & 02 & 03 & 04 & 05 & 06 & 07 & 08 & 09 & 10 & 11 & 12 & 13 & 14 & 15 & 16 \\
\hline V4 & 28.9 & 31.2 & 25.7 & 26.5 & 22.1 & 23.4 & 24.3 & 19.8 & 20.8 & 17.1 & 14.4 & 12.6 & 11.7 & 11.9 & 11.9 & 13.9 & 12.4 \\
\hline CZ & 57.9 & 63.7 & 55.8 & 46.4 & 41.7 & 35.4 & 24.6 & 19.2 & 20.8 & 24.1 & 23.6 & 23.1 & 16.9 & 17.4 & 13.2 & 19.4 & 28.5 \\
\hline HU & 30.1 & 27.3 & 20.2 & 18.1 & 15.9 & 17.3 & 16.2 & 15.4 & 16.0 & 17.1 & 15.6 & 19.2 & 19.7 & 20.4 & 31.8 & 32.4 & 30.3 \\
\hline PL & 23.6 & 26.4 & 19.3 & 15.0 & 22.3 & 23.7 & 26.1 & 19.6 & 18.6 & 12.6 & 10.8 & 10.7 & 9.8 & 9.4 & 9.6 & 8.4 & 5.1 \\
\hline SK & 29.6 & 31.1 & 34.0 & 34.9 & 21.9 & 22.7 & 27.3 & 26.6 & 26.2 & 14.3 & 9.2 & 7.9 & 7.8 & 5.5 & 6.7 & 4.1 & 5.7 \\
\hline
\end{tabular}

Source: author's calculations

In most years, the liquidity of Czech and Hungarian banking sectors is above average within V4 countries which is proved by higher values of the LITA ratio and lower values of the 
LOTA ratio (Table 1 and Table 2). Czech banking sector was the most liquid in the first half of the period. Mainly large and medium-sized banks held the very high level of liquid assets, especially short-term claims on other banks. After that, these banks started to focus more on lending to non-bank customers which resulted in lower values of the LITA ratio (and higher values of the LOTA ratio). The situation in the Hungarian banking sector was completely opposite: mainly medium-sized banks lowered their lending activity and increased their liquidity buffer in the second half of the analysed period. Polish and Slovak banks on average behave similarly: they held the very low level of liquid assets since 2010 and they gradually increased their lending activity during the whole analyzed period.

Table 2: Median values of the LOTA ratio

\begin{tabular}{|l|c|c|c|c|c|c|c|c|c|c|c|c|c|c|c|c|c|}
\hline & 00 & 01 & 02 & 03 & 04 & 05 & 06 & 07 & 08 & 09 & 10 & 11 & 12 & 13 & 14 & 15 & 16 \\
\hline V4 & 47.4 & 43.8 & 46.8 & 48.6 & 47.7 & 49.7 & 56.5 & 60.5 & 63.9 & 65.2 & 63.6 & 65.7 & 62.5 & 63.2 & 64.3 & 63.3 & 66.8 \\
\hline CZ & 30.7 & 31.7 & 36.9 & 38.6 & 45.8 & 47.4 & 59.5 & 56.8 & 69.7 & 63.5 & 58.9 & 54.1 & 57.5 & 54.7 & 55.1 & 57.9 & 55.2 \\
\hline HU & 63.6 & 60.9 & 64.0 & 67.7 & 69.5 & 69.4 & 71.7 & 74.8 & 71.5 & 69.6 & 69.3 & 66.0 & 58.2 & 60.0 & 57.5 & 51.0 & 51.5 \\
\hline PL & 47.9 & 42.6 & 47.5 & 52.8 & 45.4 & 48.5 & 55.0 & 66.4 & 64.6 & 67.5 & 67.3 & 70.2 & 67.4 & 70.5 & 70.3 & 69.1 & 71.5 \\
\hline SK & 26.1 & 34.0 & 37.4 & 37.5 & 35.8 & 37.8 & 42.0 & 50.1 & 50.5 & 59.0 & 59.8 & 64.0 & 64.7 & 63.3 & 68.0 & 70.5 & 75.0 \\
\hline
\end{tabular}

Source: author's calculations

The way how banks finance their lending activity also affects the level of their liquidity. In all analyzed banking sectors, some banks can provide their loans only from clients' deposits, while some other banks are strongly dependent also on other sources of funding, at least in some years (Table 3). As clients' deposits are considered as a more stable source of funding, Czech and Slovak banks are less vulnerable (they reached lower values of the LODE ratio than Polish and Hungarian banks), especially during market turmoil.

Table 3: Median values of the LODE ratio

\begin{tabular}{|l|c|c|c|c|c|c|c|c|c|c|c|c|c|c|c|c|c|}
\hline & 00 & 01 & 02 & 03 & 04 & 05 & 06 & 07 & 08 & 09 & 10 & 11 & 12 & 13 & 14 & 15 & 16 \\
\hline V4 & 92.8 & 82.1 & 84.5 & 84.9 & 84.2 & 86.2 & 92.8 & 103 & 102 & 99.1 & 98.1 & 94.2 & 92.1 & 92.3 & 91.3 & 88.7 & 91.2 \\
\hline CZ & 47.2 & 43.4 & 49.3 & 56.4 & 78.2 & 87.0 & 91.7 & 95.9 & 102 & 88.7 & 75.6 & 79.3 & 80.1 & 78.8 & 80.8 & 80.8 & 77.6 \\
\hline HU & 124 & 105 & 117 & 120 & 128 & 137 & 139 & 129 & 182 & 159 & 157 & 117 & 108 & 99.6 & 93.2 & 77.0 & 75.5 \\
\hline PL & 92.8 & 82.1 & 87.1 & 85.7 & 78.4 & 68.2 & 87.1 & 109 & 99.3 & 99.0 & 95.3 & 96.6 & 93.1 & 92.5 & 96.1 & 96.1 & 97.9 \\
\hline SK & 44.4 & 51.4 & 55.0 & 53.2 & 59.1 & 62.8 & 82.7 & 97.2 & 82.6 & 86.8 & 95.9 & 95.1 & 88.9 & 93.9 & 104 & 97.7 & 93.0 \\
\hline
\end{tabular}

Source: author's calculations

Banks who are net borrowers on the interbank market are much more vulnerable they net lenders. In case of any doubts about their financial situation, lenders may not roll over their loans. It is, therefore, useful to assess also the last liquidity ratio: the share of net interbank position in total assets (Table 4). With the exception of 2015, Czech banking sector as a whole is a net lender for the whole analyzed period. Together with a sufficient level of liquid assets, reasonable lending financed mainly from clients' deposits, we can conclude that in terms of liquidity, Czech banks are the safest within the V4 countries. On the contrary, Hungarian banks are net borrowers in the whole analyzed period. Especially in crisis years, their net interbank position was really large. Their activities on the interbank market, together with higher dependence on other sources of funding (reflected in higher LODE ratio) increased their vulnerability. However, the buffer of liquid assets of Hungarian banks remained sufficient even in crisis years.

Table 4: Median values of the NIP ratio

\begin{tabular}{|c|c|c|c|c|c|c|c|c|c|c|c|c|c|c|c|c|c|}
\hline & 00 & 01 & 02 & 03 & 04 & 05 & 06 & 07 & 08 & 09 & 10 & 11 & 12 & 13 & 14 & 15 & 16 \\
\hline V4 & 8.1 & 8.0 & 8.4 & 2.7 & 1.9 & 1.9 & 2.0 & \begin{tabular}{|l|}
0.1 \\
\end{tabular} & -1.7 & -1.1 & -1.0 & -1.4 & -3.0 & -2.0 & -2.8 & -1.9 & 0.2 \\
\hline $\mathrm{CZ}$ & 26.6 & 25.7 & 28.3 & 36.8 & 29.0 & 15.5 & 11.2 & 7.6 & 2.3 & 3.8 & 9.7 & 0.1 & 2.4 & 0.9 & 0.2 & -0.1 & 0.7 \\
\hline $\mathrm{HU}$ & -7.4 & -8.1 & -5.9 & -15 & -10 & -10 & -16 & -18 & -26 & -32 & -29 & -21 & -11 & -14 & -5.3 & -2.7 & -0.6 \\
\hline $\mathrm{PL}$ & 2.7 & 4.6 & 2.8 & 1.9 & $\begin{array}{ll}1.1 \\
\end{array}$ & -3.1 & 1.0 & -5.5 & -1.8 & 2.0 & -0.4 & -0.4 & -0.0 & -1.2 & -2.3 & -1.9 & -0.0 \\
\hline SK & 17.1 & 19.7 & 14.4 & 10.8 & 10.3 & 8.5 & 2.3 & 3.1 & 0.9 & $\begin{array}{l}-4.2 \\
\end{array}$ & 0.2 & -2.8 & \begin{tabular}{|l|}
-3.3 \\
\end{tabular} & $\begin{array}{l}-1.8 \\
\end{array}$ & \begin{tabular}{|l|}
-3.9 \\
\end{tabular} & $\begin{array}{l}-0.1 \\
\end{array}$ & -0.2 \\
\hline
\end{tabular}

Source: author's calculations 
Slovak banking sector as a whole was in a position of the net lender in the first half and net borrower in the second half of the period. The situation in Polish banking sector is similar, not only in terms of interbank market activities but with respect to the level of liquid assets, lending activity and their sources of funding. Polish and Slovak banks are less liquid and more vulnerable than Czech and Hungarian banks.

Table 5: Median values of the CAP ratio

\begin{tabular}{|c|c|c|c|c|c|c|c|c|c|c|c|c|c|c|c|c|c|}
\hline & 00 & 01 & 02 & 03 & 04 & 05 & 06 & 07 & 08 & 09 & 10 & 11 & 12 & 13 & 14 & 15 & 16 \\
\hline V4 & 11.4 & 10.2 & 11.5 & 11.3 & 11.7 & 11.1 & 11.1 & 10.7 & 10.7 & 11.8 & 12.2 & 12.0 & 13.0 & 13.7 & 14.4 & 14.6 & 15.3 \\
\hline $\mathrm{CZ}$ & 12. & 13.9 & 16.6 & 14.1 & 13.3 & 11.1 & 11 & 10.5 & 11. & 12.3 & 14.2 & 13.2 & 13.7 & 15.4 & 15.2 & 13.9 & 13.7 \\
\hline $\mathrm{HU}$ & 10.5 & 10.1 & 10.1 & 10.2 & 10.6 & 10.5 & 10.7 & 10.4 & 10.0 & 11.7 & 11.9 & 10.5 & 12.5 & 14.2 & 15.8 & 15.1 & 14.2 \\
\hline PL & 10.4 & 9.4 & 10.1 & 9.6 & 10.7 & 12.3 & 11.7 & 11.9 & 10.9 & 12.5 & 12.0 & 11.9 & 13.9 & 13.4 & 14.1 & 14.6 & 15.8 \\
\hline SK & 13.7 & 14.2 & 16.9 & 18.1 & 13.6 & 11.5 & 9.7 & 10.3 & 9.3 & 10.4 & 11.4 & 12.2 & 12.8 & 13.5 & 14.4 & 15.5 & 16.2 \\
\hline
\end{tabular}

Source: author's calculations

As it was mentioned above, bank liquidity may be connected also with bank solvency. Values of the share of equity in total assets are presented in Table 5. With the exception of last two years, capital adequacy (solvency) of Czech banks is above average. Solvency of Polish and Hungarian banks was substantially lower; however, it improved significantly in last few years. Capital adequacy of Slovak banks was above average in 2000-2005 and in last three years.

As the aim of this paper is also to determine whether banks that belong to a financial conglomerate are more or less liquid and solvent than other banks in the sector, now we will focus directly on individual banks of financial conglomerates. Table 6 shows the average values of selected liquidity and solvency ratios of banks that belong to one of five chosen financial conglomerates: Erste Group (ERSTE), KBC Group (KBC), Raiffeisen Bank International AG (RBI), Société Générale Group (SG) and UniCredit Group (UNIC). We will examine whether these banks achieved liquidity and solvency above or below the median value in each Visegrad country.

Table 6: Average indices in the banks of financial conglomerates during 2000-2016

\begin{tabular}{|c|c|c|c|c|c|c|}
\hline Group & Bank & LITA & LOTA & LODE & NIP & CAP \\
\hline \multicolumn{7}{|c|}{ The Czech Republic } \\
\hline \multicolumn{2}{|c|}{ Czech Republic - median } & 31.3 & 51.4 & 76.0 & 11.8 & 13.3 \\
\hline ERSTE & Ceska sporitelna & 30.2 & 34.6 & 65.6 & 8.8 & 12.5 \\
\hline $\mathrm{KBC}$ & CSOB & 33.6 & 46.6 & 52.5 & 8.5 & 18.8 \\
\hline RBI & Raiffeisenbank & 25.8 & 66.9 & 103.6 & -1.5 & 7.9 \\
\hline SG & Komercni banka & 36.3 & 46.0 & 62.6 & 24.2 & 16.9 \\
\hline UNIC & UniCredit Bank Czech Republic and Slovakia & 20.1 & 60.9 & 98.5 & 3.2 & 15.5 \\
\hline \multicolumn{7}{|c|}{ Hungary } \\
\hline \multicolumn{2}{|c|}{ Hungary - median } & 21.4 & 64.5 & 121.8 & -13.7 & 11.7 \\
\hline ERSTE & Erste Bank Hungary & 18.0 & 53.6 & 77.3 & -7.1 & 17.7 \\
\hline $\mathrm{KBC}$ & K\&H Bank & 24.6 & 43.3 & 63.0 & 7.5 & 15.3 \\
\hline RBI & Raiffeisen Bank & 31.2 & 46.8 & 70.4 & 0.4 & 19.3 \\
\hline UNIC & UniCredit Bank & 31.7 & 42.2 & 74.5 & -4.3 & 20.3 \\
\hline \multicolumn{7}{|c|}{ Poland } \\
\hline \multicolumn{2}{|c|}{ Poland - median } & 15.9 & 60.3 & 91.5 & -0.1 & 12.1 \\
\hline RBI & Raiffeisen Bank Polska & 23.5 & 63.8 & 103.5 & -9.9 & 10.5 \\
\hline SG & Euro Bank & 9.3 & 78.0 & 189.7 & 13.6 & 12.0 \\
\hline UNIC & Bank Pekao & 16.2 & 57.5 & 76.7 & -2.8 & 16.6 \\
\hline \multicolumn{7}{|c|}{ Slovakia } \\
\hline \multicolumn{2}{|c|}{ Slovakia - median } & 18.6 & 51.5 & 79.0 & 4.2 & 13.2 \\
\hline ERSTE & Slovenska sporitelna & 26.4 & 44.5 & 93.4 & 5.5 & 18.2 \\
\hline KBC & CSOB & 16.1 & 51.7 & 86.0 & -3.7 & 9.3 \\
\hline RBI & Tatrabanka & 18.1 & 56.1 & 217.9 & 5.8 & 13.8 \\
\hline
\end{tabular}

Source: author's calculations 
We found that Czech and Hungarian banks that belong to KBC Group are more liquid and solvent than it is typical for those two banking sectors. However, CSOB from Slovakia is slightly less liquid and much less solvent than other banks in Slovakia.

Results for banks from Erste Group are different. Slovenska sporitelna has better both liquidity and solvency (with the exception of the LODE ratio) than the median value for the Slovakian banking sector. On the contrary, although Czech Ceska sporitelna and Hungarian $\mathrm{K} \& \mathrm{H}$ Bank hold a lower buffer of liquid assets, they provide fewer loans to non-bank customers and also the financing of these loans is less risky. Looking on solvency, capital adequacy ratio of Ceska sporitelna is below average, the same ratio for $\mathrm{K} \& \mathrm{H}$ Bank is above average.

The banks from the Raiffeisen Bank International AG achieved also different results. Hungarian Raiffeisen Bank and Slovak Tatrabanka are more solvent, Czech Raiffeisenbank and Polish Raiffeisen Bank Polska are less solvent than the median for these banking sectors. In Poland and Hungary, banks are more liquid (in Poland with the slightly worse financing of lending activity). On the contrary, Czech and Slovak banks from the RBI Group achieved worse values of liquidity due to their higher lending activity.

In case of the UniCredit Group, banks in all three countries are much more solvent. Liquidity of Unicredit Bank Czech Republic and Slovakia is significantly lower in terms of all four ratios. On the other hand, Hungarian UniCredit Bank and Polish Bank Pekao are substantially more liquid than other Hungarian and Polish banks.

Results for banks from the Société Générale Group are completely mixed: Komercni banka is more liquid and solvent than other Czech banks but Euro Bank has lower both liquidity and solvency.

It is possible to say that all banks that belong to a financial conglomerate in Hungary are more solvent and mostly (with the exception of lower LITA ratio for Erste Bank Hungary) more liquid than other banks in the Hungarian banking sector. However, the results are mixed for the Czech Republic, Poland, and Slovakia.

Table 7: Average indices in financial conglomerates in V4 during 2000-2016

\begin{tabular}{|l|r|r|r|r|r|}
\hline Financial conglomerate & LITA & LOTA & LODE & NIP & CAP \\
\hline V4 median & 19.3 & 57.6 & 91.8 & 1.1 & 12.2 \\
\hline ERSTE & 25.7 & 51.6 & 87.1 & -3.1 & 14.1 \\
\hline KBC & 26.8 & 46.7 & 74.0 & 0.3 & 11.7 \\
\hline RBI & 20.6 & 63.9 & 134.0 & -3.8 & 11.3 \\
\hline SG & 30.6 & 55.1 & 104.2 & 23.6 & 13.5 \\
\hline UNIC & 23.8 & 57.0 & 84.4 & 0.4 & 15.2 \\
\hline
\end{tabular}

Source: author's calculations

When we analyzed the banks in financial conglomerates in Visegrad countries together (Table 7), we found that banks from all five financial groups held a higher buffer of liquid assets than it is usual in the Visegrad countries (their LITA ratio is substantially higher than the median for V4 countries). The higher buffer of liquid assets is connected (with the exception of RBI) with lower lending activity. Erste Group, KBC Group, and UniCredit Group are safer in terms of the way how they finance their lending activity; RBI and SG need also other sources of funding. With the only exception of Société Générale Group, banks from other financial groups have a worse position on the interbank market than the median for the Visegrad countries. Banks from KBC and RBI are less solvent; the capital position of banks from ERSTE, KBC, and UNIC is more suitable. 
As we can see, the results are mixed. Therefore we cannot confirm that banks in a financial conglomerate are more or less liquid and solvent than other banks in the banking sector. Our conclusion is in accordance with findings of Palečková (2017) who also did not confirm that banks from a financial conglomerate are more or less efficient than other banks in the banking sector in the Visegrad countries. It seems that an affiliation with a financial conglomerate is not the determinant of bank liquidity and solvency. Therefore, further research could focus on the examination of the determinants of banking liquidity and solvency in selected banking sectors.

\section{Conclusion}

The aim of this paper was to evaluate the liquidity and solvency of commercial banks in the Visegrad countries during the 2000-2016 period and to determine whether banks that belong to a financial conglomerate are more or less liquid and solvent than other banks in the sector.

As bank liquidity is strongly influenced by lending policy of the bank (how much the bank lend to non-bank customers, what sources of funding the bank use) and by activities of bank on the interbank market, we focused on four liquidity ratios: the share of liquid assets in total assets, the share of loans in total assets, the share of loans in deposits and the share of net interbank position in total assets. We have calculated these ratios for all banks in the sample. In terms of liquidity, Czech banks are the safest. They hold a high level of liquid assets, they lend reasonably and finance it mainly from clients' deposits and they are net lenders on the interbank market. Due to their sufficient buffer of liquid assets, Hungarian banks can be seen as quite safe as well, in spite of their negative net position on the interbank market and higher dependence on other sources of funding. Liquidity of Slovak and Polish banks is worse, mainly in the second half of the analyzed period. Polish and Slovak banks are much more vulnerable than Czech and Hungarian banks. We assessed bank solvency by the share of equity in total assets, again for all banks in the sample. Focusing on the whole analyzed period, Czech and Slovak banks have the highest capital adequacy. Solvency of Polish and Hungarian banks was substantially lower; however, it improved significantly in last few years.

All banks that belong to a financial conglomerate in Hungary are more solvent and mostly more liquid than other banks in the Hungarian banking sector. However, the results are mixed for other Visegrad countries. Focusing on banks from financial conglomerates in the Visegrad countries together, we found that banks from all analyzed groups held a higher buffer of liquid assets and mostly focus less on providing loans to non-bank customers. Results for other liquidity ratios and for capital adequacy ratio are not so unambiguous.

As the results are mixed (for individual financial groups, individual countries, individual financial ratios), we cannot confirm that banks in a financial conglomerate are more or less liquid and solvent than other banks in the banking sector.

\section{Acknowledgement}

Publication of this paper was supported by the Czech Science Foundation (Project GAČR 1617796S, Affiliation with financial conglomerate as a determinant of performance and risk of banks). The support is gratefully acknowledged. 


\section{References}

[1] BERGER, A. N. and C. H. S. BOUWMAN, 2009. Bank Liquidity Creation. Review of Financial Studies, 22(9), 3779-3837. ISSN 0893-9454.

[2] BERROSPIDE, J., 2013. Bank Liquidity Hoarding and the Financial Crisis: An Empirical Evaluation. Finance and Economics Discussion Series of Federal Reserve Board, 03.

[3] BIKKER, J. A. and P. A. J. METZEMAKERS, 2007. Is bank capital procyclical? A cross-country analysis. Kredit und Kapital, 40(2), 225-264. ISSN 2199-1227.

[4] BIS, 2008. Principles for Sound Liquidity Risk Management and Supervision. Basel: Bank for International Settlements. ISBN 92-9197-767-5.

[5] DIAMOND, W. D. and R. G. RAJAN, 2001. Liquidity Risk, Liquidity Creation and Financial Fragility: A theory of banking. Working paper of National Bureau of Economic Research no. 7430.

[6] DIERICK, F., 2004. The supervision of mixed financial services groups in Europe. ECB Occasional Paper No. 20. Frankfurt am Main: European Central Bank.

[7] DINGER, V., 2009. Do foreign-owned banks affect banking system liquidity risk? Journal of Comparative Economics, 37(4), 647-657. ISSN 0147-5967.

[8] DISTINGUIN, I., C. ROULET and A. TARAZI, 2013. Bank regulatory capital and liquidity: Evidence from US and European publicly traded banks. Journal of Banking and Finance, 37(9), 3296-3317. ISSN 0378-4266.

[9] ECB, 2002. Developments in Banks' Liquidity Profile and Management. Frankfurt am Main: European Central Bank. ISBN 92-9181-291-9.

[10] GORTON, G. and A. WINTON, 2000. Liquidity Provision, Bank Capital, and the Macroeconomy. Working Paper of the University of Minnesota.

[11] LEI, A. C. H. and Z. SONG, 2013. Liquidity creation and bank capital structure in China. Global Financial Journal, 24(3), 188-202. ISSN 1044-0283.

[12] MUNTEANU, I. Bank liquidity and its determinants in Romania. Procedia Economics and Finance, 2012(3), 993-998. ISSN 2212-5671.

[13] PALEČKOVÁ, I., 2017. Efficiency Change of Banking Sectors and Banks in the Financial Conglomerates in Visegrad Group Countries. Ekonomický časopis/Journal of Economics, 65(1), 79-92. ISSN 0013-3035.

[14] RUOZI, R. and P. FERRARI, 2013. Liquidity Risk Management in Banks. Economic and Regulatory Issues. Heidelberg: Springer. ISBN 978-3-642-29580-5.

[15] VANDER VENNET, R., 2002. Cost and Profit Efficiency of Financial Conglomerates and Universal Banks in Europe. Journal of Money, Credit, and Banking, 34(1), 254-282. ISSN 1538-4616.

[16] VENTO, G. A. and P. LA GANGA, 2009. Bank Liquidity Risk Management and Supervision: Which Lessons from Recent Market Turmoil? Journal of Money, Investment and Banking, 2009(10), 79-126. ISSN 1450-288X.

[17] VODOVÁ, P., 2013a. Liquid assets in banking: What matters in the Visegrad Countries? E+M Ekonomie + Management, 16(3), 113-129. ISSN 1212-3609. 
[18] VODOVÁ, P., 2013b. Liquidity risk of banks in the Visegrad Countries. An empirical analysis of bank liquidity, its determinants and liquidity risk sensitivity. Saarbrücken: Lambert Academic Publishing. ISBN 978-3-659-49360-7.

[19] VODOVÁ, P., 2015. To Lend or to Borrow on the Interbank Market: What Matters for Commercial Banks in the Visegrad Countries. Prague Economic Papers, 24(6), 662-677. ISSN 1210-0455. 